\title{
Peptide Synthesis
}

National Cancer Institute

\section{Source}

National Cancer Institute. Peptide Synthesis. NCI Thesaurus. Code C16966.

The sequential formation of peptide bonds between amino acids 